\title{
PRIVATE COLLEGES, STATE AID, AND THE ESTABLISHIVENT CLAUSE
}

Private colleges throughout the United States are confronting a financial crisis generated by inflation, rising faculty salaries and operating costs, and the need for up-to-date equipnent in order to supply a quality education. ${ }^{1}$ If this situation continues a large number of private colleges nuay be forced to increase their tuition greatly or even to close their doors. $^{2}$ Either event would have the effect of thrusting a host of students back onto public university systems, ${ }^{3}$ an eventuality which would necessitate the expenditure of large sums of noney for the expansion of existing state university facilities. ${ }^{4}$ Accordingly, the desirability of state aid to private colleges and universities, either through direct grants to those institutions or through tuition aid to their students, has becone increasingly apparent to state legislatures. ${ }^{5}$

However, while such assistance is justified for both economic and policy reasons, ${ }^{6}$ a potential obstacle ${ }^{7}$ is presented by the establishinent

1. Americans United for Separation of Church \& State v. Bubb, 379 F. Supp. 872, 877 (D. Kan. 1974).

2. See Wang, The Unbundling of Higher Education, 1975 DuKE L.J. 53, 54-55 n.4; The Squeeze on Education, Forkes, Sept. 15, 1974, at 37; Too Little, Too Late, NEwsweEk, Jan. 14, 1974, at 58. See generally CARNEGIE COMM'N ON Higher EduCATION, Higher Education; Who Pays? Who Benefrts? Who Should Pay? (1973).

3. See Constiturionality of Federal Aid to Education in Its Various AsPECTS, S. Doc. No. 29, 87th Cong., 1st Sess. (1961) (prepared by Department of Health, Education, and Welfare) reprinted as Memorandum on the Impact of the First Amendment to the Constitution upon Federal Aid to Education, 50 Geo. L.J. 349, 379-80 (1961).

4. See Memorandum, supra note 3 , at 379.

5. The states which have enacted statutes providing aid to private colleges or to the students at those colleges include Maryland, Tennessee, and Kansas. This legislation will be specifically considered later in this Note. See notes 65-135 infra and accompanying text. The Tennessee tuition grant program was recently repealed and a loanscholarship program was enacted in its place. Ch. 620, \$27 [1974] Tenn. Acts; TenN. CODE ANN. \& 49-5001 to -25 (1974).

6. Along with a legislature's desire to imsure that everyone who wishes to obtain a college education can do so, an additional policy consideration is the prevention of the establishment of secularisin. Noting that most private schools and colleges are church-affiliated and that they may be unable to operate because of mounting financial difficulties, some commentators fear that only public educational systems will be available in future years. The cultural effect, they argue, would be the establishment of a religion of secularism. See Gellhorn \& Greenawalt, Public Support and the Sectarian University, 38 Fordiam L. REv. 395, 418-21 (1970). One commentator explains the development of a "religion of secularism" in this manner: 
clause of the first amendment. ${ }^{8}$ Many private colleges and universities are associated with religious groups. ${ }^{9}$ Although in most cases the relationship is only formalistic, aid provided by the state to students at these institutions, or to the colleges theniselves, arguably "establishes" the affiliated denomination and is therefore a violation of the Constitution. ${ }^{10}$

[S]ecular treatment unavoidably tends to belittle both Protestant and Catholic dogma and hence may perlaps be characterized as indoctrinating antireligionism or secular religionism. Similarly, a civics class in racial discrimination would invoke the equality value but would ignore its religious source, associating the value with Americanism or some other secular ethic. Ignoring the theological source of the imperative-and, worse, supplying an alternative secular source-tends to belittle, perhaps even negate, the theological. Religion is most necessary, and lience most believable, when it provides the sole explanation for all plenomena. A system which provides answers without reference to religion or which teaches that there are no answers makes religion less necessary, and hence less believable. Schwarz, No Imposition of Religion: The Establishment Clause Value, 77 YALE L.J. 692, 700-01 (1968) (footnote omitted).

See also Note, Voucher Systems of Public Education After Nyquist and Sloan: Can A Constitutional System Be Devised?, 72 Mich. L. Rev. 895, 905-06 (1974).

7. Many states' aid-to-ligher-education statutes have been struck down by federal and state courts on establishment clause grounds. See Americans United for the Separation of Cliurch \& State v. Dunn, 384 F. Supp. 714 (M.D. Tenn. 1974), vacated, 43 U.S.L.W. 3598 (May 12, 1975); Minnesota Civil Liberties Union v. State, - Minn. -, 224 N.W.2d 344 (1974), petition for cert. filed, 43 U.S.L.W. 3516 (Mar. 17, 1975); State ex rel. Rogers v. Swanson, 192 Neb. 125, 219 N.W.2d 726 (1974); Almord v. Day, 197 Va. 419,89 S.E.2d 851 (1955); Weiss v. Bruno, 82 Wash. $2 d$ 199, 509 P.2d 973 (1973). The Alabama House of Representatives has been advised by the state Supreme Court that proposed legislation providing aid to students at private colleges would be in violation of the United States Constitution. Opinion of the Justices, 291 Ala. 301, 280 So. 2 d 547 (1973).

8. U.S. CoNST. amend. I, provides in pertinent part: "Congress shall make no law respecting an establishment of religion, or prohibiting the free exercise thereof ...." For a discussion of the policies reflected in the first amendment and various commentators' views on these policies, see Note, Aid to Parochial Schools: A Re-Examination, 14 WM. \& MaRY L. REv. 128 (1972).

9. In Kansas, all nineteen of the qualified colleges under the state's tuition grant program were associated, in varying degrees, with religious groups. Americans United for Separation of Church \& State v. Bubb, 379 F. Supp. 872, 878-85 (D. Kan. 1974). In the two years that a tuition grant program was in operation in Tennessee, an average of eighty-five percent of all aid going to private schools went to church-affiliated colleges. Americans United for the Separation of Church \& State v. Dunn, 384 F. Supp. 714, 717 (M.D. Tenn. 1974). In Roemer v. Board of Pub. Works, 387 F. Supp. 1282 (D. Md. 1974), prob. juris. noted, 43 U.S.L.W. 3515 (Mar. 25, 1975), five of eighteen eligible schools were church-related. 387 F. Supp. at 1284.

10. This Note will not attempt to deal with state constitutional provisions prohibiting aid to religion. State constitutions are typically more specific than the United States Constitution and hence it may be more difficult for a state aid program to meet state constitutional requirements. For example, the South Carolina Constitution provides in pertinent part:

The property or credit of the State of South Carolina . . . shall not ... be used, directly or indirectly, in aid or maintenance of any college ... which is wholly or in part under the direction or control of any church or of any 
This Note will first briefly trace the Supreme Court's treatment of the establishment clause in relation to government aid to elementary, secondary, and higher education. It will then focus upon three recent decisions by federal district courts ${ }^{11}$ which considered the constitutionality of state legislation designed to ease the financial burdens on private institutions of higher learning, and will offer a critical analysis of the way in which those courts resolved the important and complex issues before them.

\section{The Supreme Court and the Establishment Clause}

The first decision of the Supreme Court which directly considered the prohibitions of the establishment clause in the context of state aid to private education was Everson v. Board of Education. ${ }^{12}$ Justice Black, writing for the majority, quoted with approval Thomas Jefferson's statement that the clause was intended to erect "a wall of

religious or sectarian denomination, society, or organization. S.C. CoNST. art. $\mathrm{XI}, \$ 9$.

See Hartness v. Patterson, 255 S.C. 503, 179 S.E.2d 907 (1971); Miller v. Ayres, 213 Va. 251, 191 S.E.2d 261 (1972) (aid program violated the state constitution but not the establishment clause).

11. Roemer v. Board of Pub. Works, 387 F. Supp. 1282 (D. Md. 1974) prob. juris. noted, 43 U.S.L.W. 3515 (Mar. 25, 1975); Americans United for Separation of Church \& State v. Bubb, 379 F. Supp. 872 (D. Kan. 1974); Americans United for the Separation of Church \& State v. Dunn, 384 F. Supp. 714 (M.D. Tenn. 1974).

12. 330 U.S. 1 (1947). In two earlier cases, Bradfield v. Roberts, 175 U.S. 291 (1899), and Quick Bear v. Leupp, 210 U.S. 50 (1908), the Supreme Court was confronted with establishment clause challenges but was able to reach decisions without discussing the limits of the first amendment to any great degree. In Bradfield, the petitioner alleged that the Commissioner of the District of Columbia violated the establishment clause by appropriating funds for the construction of a building on the grounds of a hospital operated by a corporation controlled by the Sisters of the Roman Catholic Church. The building was to be used for the care of poor patients and the District was to pay the hospital for treatment rendered. The Court dismissed the fact that the corporation running the hospital was controlled and operated by a religious order as "wholly immaterial." 175 U.S. at 298. It found that there was "nothing sectarian in the corporation, and 'the specific and limited object of its creation' is the opening and keeping a hospital in the city of Washington. . . ." Id. at 299.

Quick Bear was the first decision of the Supreme Court dealing with governmental aid to sectarian schools. The petitioners were members of the Sioux tribe challenging an appropriation of funds by the Secretary of the Interior out of the Sioux's "Trust Fund" and "Treaty Fund" for a sectarian education for the tribe. Basing its argument on Bradfield, the government maintained that a school cannot be an establishment of religion simply because there is instruction in morality and religion along with a secular education. 210 U.S. at 74 . The goverument's second argument was that the funds belonged to the Sioux and not to the government, and that the Secretary, as trustee, could spend the funds to provide a religious education if some of the Sioux wished. The Court ignored the first argument and held that the funds belonged to the Sioux, and that the expenditure of funds by the Secretary was not a governmental expenditure. Id. at 8081. 
separation between Church and State,"13 but nevertheless went on to uphold a New Jersey Board of Education's reimbursement of student bus fares to parents of children attending sectarian schools, as well as public schools. ${ }^{14}$ The Court indicated that the proper stance for government to take toward religious groups was one of neutrality, ${ }^{15}$ likening the payment of bus fares to the government's provision of such inunicipal services as police and fire protection, sewage disposal, and the building and maintenance of highways and sidewalks. ${ }^{16}$ The Court distinguished direct aid to parents from impermissible aid to religious groups:

The State contributes no money to the schools. It does not support them. Its legislation as applied, does no more than provide a general program to help parents get their children, regardless of their religion, safely and expeditiously to and from accredited schools.17

13. 330 U.S. at 16. See Reynolds v. United States, 98 U.S. 145, 164 (1878).

14. 330 U.S. at 17. The Court upheld a New Jersey statute which authorized local school districts to contract for the transportation of children to and from schools. Although the statute said nothing specifically about the transportation of students to sectarian schools, it did mention that schools other than public schools were included. Pursuant to the statute, a local school board reimbursed parents of children in Catholic schools for their bus fares on public transportation.

15. Id. at 18. See P. KuRLAND, RELIGION AND THE LAW 18 (1962).

16. 330 U.S. at 17-18. In Otero v. New York City Housing Authority, 484 F.2d 1122 (2d Cir. 1973), the Second Circuit indicated that it would uphold the Housing Authority's establishment of housing priorities for Hasidic Jews so that they could live near their synagogue if the priority was granted on nonreligious criteria. The court said that if the evidence showed the priorities were granted because of the need to protect the families from physical and verbal abuse suffered in walking the longer distance to the synagogue from their previous apartments, the Authority's action would be permissible. In essence, if the city could show that its action, though facilitating religious observance, was simply an attempt to ensure the safety of the families, it would be constitutional. In Bertch v. Social Welfare Dep't., 45 Cal. 2d 524, 289 P.2d 485 (1955), a California court upheld old-age support payments to people who lived in a home operated by a religious group. The court said:

[T] he care and rehef of aged persons who are in need is a special matter of state concern and .... the enactment of the Old Age Security Law, based upon a broad social policy, did not constitute a gift of public money within the constitutional prohibition. Id. at 534, 289 P.2d at 491 .

17. 330 U.S. at 18. The distinction between aiding students who happen to attend sectarian schools and aiding sectarian schools directly may be crucial to the constitutionality of a tuition aid program. In Board of Educ. v. Allen, 392 U.S. 236 (1968), the Supreme Court upheld New York's practice of loaning secular textbooks to students in parochial secondary schools. The Court, relying on Everson, said, "The law merely makes available to all children the benefits of a general program to lend school books free of charge." Id. at 243. Though the Court pointed out that the financial benefit was to parents and children and not to the sectarian schools, it did admit that the program unade it likely that some children would attend parochial schools who otherwise might not. Id. at 244. It also analogized the secular textbooks to bus rides in that neither had any religious significance. Id. at 244-45. 
The Court acknowledged that the payment of bus fares might have the effect of permitting some children to attend parochial schools who otherwise might not because of the transportation expense,,$^{18}$ but such indirect aid to rehgion was found constitutionally permissible when resulting from a general aid to education program. ${ }^{19}$

Building on the consiclerations discussed in Everson, the Court next formulated a two-part test in School District v. Schempp, ${ }^{20}$ to be used as a framework for examining the constitutionality of governinental actions which were intended to have or did have the effect of advancing religion. The case involved a Pennsylvania statute which required the reading or recital of passages from the Bible at the beginning of each public school day. In accordance with the "neutrality principles" laid out in Everson, the Court noted that the first step in its analysis was to determine if the legislation had a secular purpose. ${ }^{21}$ If a secular legislative purpose did exist, the Court would proceed to examine whether the legislation's primary effect was to advance or imhibit religion. ${ }^{22}$ The state argued that the statute had various legitiniate secular purposes: the promotion of moral values, a counterweight to materialistic trends, the perpetuation of American institutions, and the teaching of literature. ${ }^{23}$ This argument was rejected, with the Court implying that while the purpose of the statute may not have been "strictly religious," the state could have accomplished the purported secular ends of the statute without requiring readings from the Bible, a book characterized by the Court as an "instrument of religion." ${ }^{\prime 24}$

Eight years later, this analytical framework was expanded to a three-part test in Lemon $v$. Kurtzman, ${ }^{25}$ where the Court held a

18. 330 U.S. at 17 .

19. There is a suggestion in Everson that it may be a violation of the equal protection clause to withhold a benefit from some students merely because they attend parochial schools. While the Court was careful to point out that it was not holding that a state must provide bus transportation for all children if it provides transportation to children attending public schools, it added:

[W]e must be careful in protecting the citizens of New Jersey against stateestablishred churches, to be sure that we do not inadvertently prohibit New Jersey from extending its general state law benefits to all its citizens without regard to their religious belief. Id. at 16.

20. 374 U.S. 203 (1963).

21. Id. at 222 .

22. $1 d$.

23. Id. at 223 .

24. Id. at 224. The Court, in effect, applied a "permissible alternatives" test. If the purposes of a statute can be accomplished without advancing or inhibiting religion, the Court is willing to assume that the purpose of the statute providing aid to religion is sectarian.

25. 403 U.S. 602 (1971). 
Rhode Island plan which provided a salary supplement to teachers in private schools unconstitutional. ${ }^{26}$ The Court also struck down a Pennsylvania statute which authorized reimbursement of private schools for money spent on teachers' salaries in specified secular courses. In these decisions, the purpose and effect considerations were supplemented by an "entanglement" analysis. ${ }^{27}$ The Court, through Chief Justice Burger, found that both the Rhode Island and Pennsylvania provisions fostered excessive administrative entanglements with rehioious groups. ${ }^{28}$ While both statutes had safeguards to ensure that state aid would not directly subsidize sectarian teachings, the Court pointed out that "comprehensive, discriminating, and continuing state surveillance" would be required to enforce the restrictions. ${ }^{29}$ In light of the extent to which religious doctrines were intertwined with the secular teachings offered by parochial elementary and secondary schools, the administrative relationships necessary to police the schools and teachers in order to ensure compliance with the secularuse restrictions in the statutes would have been too "entangling." These excessive entanglements created the possibility that the government could eventually control the operations of the religious schools. ${ }^{30}$

26. The plan specifically provided for a fifteen percent salary supplement for school teachers who taught in nonpublic schools in which the average per-pupil expenditure ou secular education was below the average in public schools. Id. at 607 .

27. Id. at 614-22. The "entauglement" consideration had been adumbrated by the Court in Walz v. Tax Comm'n, 397 U.S. 664 (1970). In Walz, the Court upheld the constitutionality of a property tax exemption for property used exclusively for religious, educational, and charitable purposes. In the Court's opinion, the legislation adopted a neutral stance toward religion, exempting all "houses of religious worship" along with property held by "nonprofit, quasi-public corporations which include hospitals, libraries, playgrounds, scientific, professional, historical, and patriotic groups." Id. at 673. One commentator has noted that the inajority opmion in Walz reflects a "neutrality of accommodation and a neutrality which, by according a central place to religious liberty, permits a preferential treatment for religion." Kauper, The Walz Decision: More on the Religion Clauses of the First Amendment, 69 МicH. L. REv. 179, 197 (1970).

28. 403 U.S. at 614 . The Court also noted that both programs had the potential of creating political divisiveness by entangling politics with religion. $I d$. at 622-24. See Freund, Public Aid to Parochial Schools, 82 Harv. L. REv. 1680, 1691-92 (1969).

29. Id. at 619. Justice Douglas, in a concurring opinion, indicated that state surveillance of the operations of parochial schools might in fact intrude on a teacher's free exercise rights. Id. at 634. See Note, Establishment Clause Analysis of Legislative and Administrative Aid to Religion, 74 CoLUM. L. REv. 1175, 1189 (1974) (suggestmg that entanglement scrutiny may be, in the last analysis, a free exercise test).

30. 403 U.S. at 625 . Alexis de Tocqueville pointed to the entangling effects that financial aid to religious groups would probably generate:

In America religion is perliaps less powerful than it has been at certain periods and among certain natious, but its influence is more lasting. It restricts itself to its own resourees, but of these none can deprive it; its circle is limited, but it pervades it and holds it under undisputed control. A. DE TOCQUEVIILE, DEMOCRACY IN AMERICA 323 (Bradley ed. 1945). 
A refinement in the three-part test was introduced in 1973 when the Supreme Court held that New York's and Pennsylvania's aid programs to private schools and aid to parents of children in private elementary and secondary schools violated the establishment clause. ${ }^{31}$ In Committee for Public Education \& Religious Liberty v. Nyquist, ${ }^{32}$ the Court struck down a New York plan under which the state assumed some of the maintenance and repair costs of private elementary and secondary schools, provided money grants to low-income parents whose children attended private schools and allowed tax credits for higher-mcome parents. ${ }^{33}$ In the companion case of Sloan $v$. Lemon, ${ }^{34}$ the Court held that a Pennsylvania tuition reimbursement plan for parents with children in nonpublic elementary and secondary schools was a violation of the establishment clause. ${ }^{35}$ Justice Powell, writing for the Court in botli cases, concluded that the statutes violated the "effect" branch of the three-part test. In reaching this conclusion, the Court changed the focus of the effect inquiry froin "primary effects" to "direct and immediate effects." have appeared to portend stricter scrutiny of the effects of aid programs, ${ }^{37}$ the Court specifically noted that a progranl providing for grants to students at both public and private educational institutions could survive an establishment clause challenge. ${ }^{38}$

31. Committee for Pub. Educ. \& Religious Liberty v. Nyquist, 413 U.S. 756 (1973); Sloan v. Lemon, 413 U.S. 925 (1973).

32. 413 U.S. 756 (1973).

33. Id. at 761-67. See generally Piekarski, Nyquist and Public Aid to Private Education, 58 MARQ. L. REv. 247 (1975).

34. 413 U.S. 825 (1973).

35. Id. at 828-29.

36. Justice Powell steadfastly maintained that it is impossible to make the "metaphysical judgment" of determining a legislative program's "primary effect." 413 U.S. at 783-84 n.39. One would have to agree that there are a number of problems with the "primary effect" concept. It is not clear whether a statute can have more than one primary effect, or whether the term means the effect which has the greatest magnitude of all effects. See Kauper, The Supreme Court and the Establishment Clause: Back to Everson?, 25 CASE W. RES. L. REv. 107, 120-21 (1974).

Justice Powell's assertion that his reformulation of the test is consistent with earlier decisions of the Court, 413 U.S. at 783-84 n.39, has been questioned by other members of the Supreme Court and at least one state court. See id. at 822-23 (White, J., dissenting); Minnesota Civil Liberties Union v. State, - Minn. -, 224 N.W.2d 344, 351-53 (1974). See also Note, supra note 29 , at 1181-82 n.43.

37. One commentator concluded that Nyquist "single-handedly extmguishes practically all hope for aid to private education." Comment, State Aid to Private Sectarian Education in Washington-Is the Coffin Nailed Slut?, 9 GoNZAGa L. REv. 791, 798 (1974). See also Cominent, Aid to Parochial Schools: A Lid on the Public Coffer, 19 ST. Lours U.L. REv. 56 (1974).

38. 413 U.S. at 782-83 n.38. The Court went on to emphasize that its decision in Nyquist did not in any way compel the conclusion that the provisions of the "G.I. Bill" violated the establishment clause. See notes 12-19 supra and accompanying text. 
Moreover, the Court has indicated that government aid to church-related colleges is not as likely to offend the establishment clause as would aid to sectarian elementary and secondary schools. In Tilton v. Richardson, ${ }^{39}$ the Court upheld the constitutionality of the Higher Education Facilities Act of $1963,{ }^{40}$ which provided federal construction grants for colleges and universities, in spite of the fact that the grants could go to church-related institutions. The Act stipulated that no grant could be used to construct any facility which would be used for sectarian purposes; if a college violated that provision within a twenty-year period beginning at completion of the project, the federal government could recover its funds. ${ }^{41}$ The Court had no difficulty finding that the Act had a secular legislative purpose, ${ }^{42}$ and also concluded that its primary effect would not be the advancement of rehigion, so long as the building could never be used for religious purposes. ${ }^{43}$ Accordingly, it severed the twenty-year limitation on recoupment of funds from the rest of the statute. ${ }^{44}$ Tilton was distinguished from Lemon on the basis of three major differences in the operation of the statutes. First, the Court indicated that the predominant function of the church-related colleges and umiversities receiving aid was to provide a secular education, as opposed to parochial elementary and secondary schools whose dominant policy is to ensure adherence to a particular faith. ${ }^{45}$ It pointed out that college students are more skeptical, less impressionable, and thus far less süsceptible to religious indoctrination than younger students. In addition, emphasis was placed on the academic freedom enjoyed by professors and students at colleges in contrast to elementary and secondary teachers and students. The Court therefore concluded that "there is less likelihood ... that rehgion will permeate the area of secular education" in colleges than in sectarian elementary and sec-

39. 403 U.S. 672 (1971).

40. Higher Education Facilities Act of 1963, Pub. L. No. 88-204, \& 101, 77 Stat. 364. The Act was repealed by Act of June 23, 1972, Pub. L. No. 92-318, $\$ 782(10)$ (b) (2), 86 Stat. 303.

41. 403 U.S. at 675 .

42. $I d$. at $678-80$.

43. Id.

44. Id. at 682-84. Justice Powell, in Nyquist, cited the severing of the twenty-year limitation from the statute im Tilton as authority for the proposition that all "direct and immediate" effects of legislation were to be examined under the effect part of the test, and for the view that the Court has never solely considered the "primary" effect of legislation. 413 U.S. at 783-84 n.39.

45. 403 U.S. at 685-87. See Freund, supra note 28, at 1691; Giannella, Religious Liberty, Nonestablishment and Doctrinal Development, Pt. II, The Nonestablishment Principle, 81 HaRv. L. Rev. 513, 583 (1968). 
ondary schools. ${ }^{40}$ Second, the Court noted that while in Lemon the state aid subsidized teachers who could project their sectarian beliefs into secular subjects, ${ }^{47}$ buildings are religiously neutral and hence the risk of the aid's promoting religion and the corresponding need for surveillance were reduced. ${ }^{43}$ Finally, the Court pointed out that the aid in Tilton was a one-time, single purpose construction grant while Lemon involved continuing appropriations for teachers' salaries; there was thus less contact between the government and a sectarian institution in Tilton. ${ }^{40}$ This last fact, coupled with the secular nature of church-related colleges and umversities, led the Court to conclude that the aid was less likely to promote political divisiveness than was the aid to elementary and secondary schools examined in Lemon. ${ }^{50}$ The Court conceded that its conclusion was difficult to substantiate, but indicated that the diversity of the student body at church-related colleges, the geographical dispersion of the students' residences, the secular character of the colleges, the lack of continuing relationships between the college and state government, and the diversity of the religious affitiations of the colleges ${ }^{51}$ were factors strengthening this position. ${ }^{52}$

The Court's recent decision in Hunt v. McNair ${ }^{53}$ provides further support for the proposition that state aid to clurch-affiliated colleges is less likely to be constitutionally impermissible than similar aid to parochial elementary and secondary schools. In Hunt, the Court upheld a South Carolina statute which provided financing for the construction of facilities to be used solely for secular purposes by a Baptist-controlled college. ${ }^{.4}$

46. 403 U.S. at 687.

47. See note 29 supra.

48. But cf. Committee for Pub. Educ. \& Religious Liberty v. Nyquist, 413 U.S. 756, 774-80 (1973) (funds for maintenance of school buildings held unconstitutional because the buildings could be used for sectarian purposes). Contra, Lemon v. Kurtzman, 403 U.S. 602, 660-61 (1971) (Brennan, J., dissenting) (arguing that it is the teaching which must be surveyed and not the buildings).

49. 403 U.S. at 688.

50. Id. at 688-89.

51. The Court used the word "diversity" but did not specify "religious diversity." Nevertheless the reference apparently was to the fact that while most eleinentary and secondary private schools in the Northeast are Roman Catholic, cf. Committee for Pub. Educ. \& Religious Liberty v. Nyquist, 413 U.S. 756, 768 (1973), greater religious diversity is represented in the affiliations of private colleges and universities.

52. 403 U.S. at $688-89$.

53. 413 U.S. 734 (1973).

54. Under the Soutl Carolina statnte, the state Educational Facilities Authority was empowered to make the funds raised by the sale of revenue bonds available to colleges. Educational Facilities Authority Act, S.C. CODE ANN. $\$ \$ 22-41$ et seq. (1969). The 
If the Court were to consider a state aid-to-higher-education statute in the near future, the three-part test apparently would be used to analyze establishment clause problems. ${ }^{55}$ It seeins safe to conclude that the purpose branch of the test will not pose a constitutional barrier to future state legislation..$^{56}$ As the Court noted in Nyquist and Sloan, there are obvious secular motivations, grounded in economic as well as pohicy considerations, for aiding private education. ${ }^{57}$ Effectively, the only way an aid-to-higher-education statute might fail a purpose scrutiny would be through an express legislative statement that one of the act's objectives is to further religious beliefs and sectarian education. ${ }^{58}$

It would be dangerous, lowever, for a state legislature to assume that the "effect" and "entanglement" aspects of the three-part test do not pose a threat to the constitutionality of aid-to-ligher education statutes. While the three-part test might at first appear to provide a mechanical formula for resolving establishment clause problems, the Court admits that the examination of aid-to-private-education plans remains a "delicate" task, dependent on a "careful evaluation of the facts of the particular case." ${ }^{\text {"59 }}$ After Nyquist, if a state aid program has the "direct and immediate effect" of aiding religion, it will be found to violate the estabhishment clause. Certainly, it is debatable whether the application of the "direct and immediate effect" test will differ from the "primary effect" test in its application, or even if "pri-

college was required to convey the facilities to the Authority and then lease the facility from the Authority until the bonds were paid in full. The Authority would then reconvey the facilities to the institution. 413 U.S. at 736-38.

55. But cf. Americans United for the Separation of Church \& State v. Dunn, 384 F. Supp. 714 (M.D. Tenn. 1974). In Dunn a three-judge federal district court refused to apply the three-part test, fashioning its own standards derived from its interpretation of Suprenne Court opinions. 384 F. Supp. at 719. See notes 65-75 infra and accompanying text.

56. In two cases where statutes were held to have an impermissible purpose, School Dist. v. Schempp, 374 U.S. 203 (1963), and Epperson v. Arkansas, 393 U.S. 97 (1968), it seemed apparent that the inain goal of the statutes was advancement of religion. For a discussion of Schempp, see text accompanying notes 20-24 supra. In Epperson, the Court found that the purpose of the legislation forbidding the teaching of the theory of evolution was "fundamentalist sectarian conviction." 393 U.S. at 107-08.

57. Coinmittee for Pub. Educ. \& Religious Liberty v. Nyquist, 413 U.S. 756, 773 (1973); Sloan v. Leinon, 413 U.S. 825, 829-30 (1973).

58. See Note, supra note 29 , at $1178-80$, for a discussion of the developinent and decline of the purpose test.

59. Wheeler v. Barrera, 417 U.S. 402, 426 (1974). Chief Justice Burger, in a separate opinion in Nyquist, implied that the Court's decisions in the religion clause cases have been inconsistent. "There is no straight line running through our decisions interpreting the Establishment and Free Exercise Clauses of the First Amendment." 413 U.S. at 799. 
mary effect" meant anything more than "direct and immediate effect" in the first place. ${ }^{60}$ Nevertheless, Nyquist stands for the proposition that a statutory aid program which has more than an incidental rehgious impact will be subjected to close constitutional scrutiny. Hence, aid flowing directly to a college that is "pervasively sectarian" or aid to a church-related school which is not restricted solely to secular use likely will be found violative of the establishment clause. ${ }^{61}$ It is also conceivable that aid to church-related colleges and universities will be found unconstitutional if such aid fosters excessive administrative entanglements between the institution and the state. ${ }^{02}$ Notwithstanding the fact that the statute has a secular-use restriction and that the aid is directed to a college which is not "pervasively sectarian," the statute might still generate excessive entanglements, particularly if the secular-use restriction would be difficult to police. ${ }^{63}$ These delicate questions, as well as others, are illustrated by several recent decisions by three-judge federal district courts grappling with the issue of whether aid-to-higher-education statutes violate the establishment clause. ${ }^{04}$

\section{Interpretations by District Courts}

In Americans United for the Separation of Church \& State $v$. Dunn, ${ }^{05}$ the District Court for the Middle District of Tennessee struck down a Tennessee statute providing for tuition grants to be paid directly to both public and private institutions for eligible students attending those schools. ${ }^{60}$ The statute placed no restrictions on the use

60. See note 36 supra and accompanying text. See also Note, supra note 29 , at 1181-86.

61. Committee for Pub. Educ. \& Religious Liberty v. Nyquist, 413 U.S. 756, 77274 (1973).

62. See id. at 794; Hunt v. Mclvair, 413 U.S. 734, 747-49 (1973); Tilton v. Richardson, 403 U.S. 672,688 (1971). It should be noted that in Nyquist the Court indicated that while the political divisiveness aspect of entanglement "may not alone warrant the invalidation of state laws that otherwise survive the careful scrutiny required by the decisions of this Court, it is certainly a 'warning signal' not to be ignored." 413 U.S. at 797-98.

63. One commentator has suggested that "[i]f an aid program successfully passes effect scrutiny, entanglement is largely superfluous." Note, supra note 29 , at 1190 . Justice Brennan's vigorous dissent in Hunt, arguing that the legislation should be struck down if it fails to pass entanglement scrutiny, seems to cast doubt on that writer's conclusion. See 413 U.S. at 749.

64. Roemer v. Board of Pub. Works, 387 F. Supp. 1282 (D. Md. 1974); Americans United for the Separation of Church \& State v. Dunn, 384 F. Supp. 714 (M.D. Tenn. 1974); Americans United for Separation of Church \& State v. Bubb, 379 F. Supp. 872 (D. Kan. 1974). All three cases were decided by three-judge courts pursuant to 28 U.S.C. $\$ \S 2281,2284$ (1970).

65. 384 F. Supp. 714 (M.D. Tenn. 1974).

66. The Tennessee Student Assistance Agency evaluated student apphications on the 
of the tuition funds by the colleges and universities, ${ }^{67}$ and many of the colleges attended by students receiving assistance were church-affiliated. ${ }^{68}$ The court declined to apply the Supreme Court's three-part test because it "obfuscated, rather than sharpened" the establishment clause inquiry. ${ }^{69}$ Instead, a different three-stage analysis was adopted. ${ }^{70}$ The first stage involved the determination of the actual recipient of the aid. According to the Dunn court, Everson established that "properly restricted" aid to students, soine but not all of whom attended church schools, was not prohibited by the establishment clause. ${ }^{71}$ However, the court concluded that the aid authorized by the Tennessee statute was not so restricted, basing its decision on "[t]he absence of restrictions in the statute, the facts concerning the operation of the program, and the actual disbursements made thereunder .972

The second stage of the analysis was an examination of whether the aid could be exclusively restricted to the institution's secular function without entangling the state in the institution's affairs. ${ }^{73}$ Since the statute contained no restriction on the expenditure of the funds, the court did not even address the problem of separating the institution's functions. ${ }^{74}$ The third aspect of the Dunn court's analysis, unnecessary for the resolution of the case, was simply that the substance, and

basis of financial need and prepared a roster of students to receive grants. After verifying that eligible students were enrolled at assigned schools, the Agency sent a draft to each institution reflecting the total amout of grants for all students eligible at the school. 384 F. Supp, at 717.

67. Id.

68. In the first year of the program's operation, fifty-nine percent of all funds distributed went to churcli-affiliated colleges. During the second year, sixty-three percent went to suclı schools. Id.

69. $1 d$. at 719 .

70. Id. at 720-21. The court believed these standards could be discerned from the Supreme Court decisions on the establishment clause. Id. at 719.

71. Id. at 720-21. The court added the following qualifications:

[T] he sovereign may not confer a "special benefit" on any particular group of students who have cliosen to support religious schools . . .; financial assistance to students must not provide an incentive for attendance at churcli-related schools . . . financial assistance to students, instead of scliools, does not give a per se immunity . . .; and direct aid in whatever form, to cliurch-related schools is invalid if no restrictions are placed thereon. Id. at 720 . (citations omitted).

In essence, despite the court's comments on the Supreme Court's three-part test, the first stage of its own analysis focuses on effect scrutiny.

72. Id. at 721 .

73. In the court's words:

[D]irect sovereign aid to church-related scliools is not unconstitutional if the aid is exclusively restricted to the secular function of those scliools, provided that the two functions can be separated and that enforcement of the restrictions does not "imvolve" or "entangle" the sovereign in religious activity. Id.

74. Id. 
not the form, of an aid program should be the crucial factor..$^{75}$

The major difference between the standards set forth in Dunn and the Supreine Court's three-part test is the absence of a "purpose" inquiry. Since this branch of the three-part test is now quite easy to meet, there is little, if any, practical difference between the two analyses.

If the tuition grants in Dunn are considered aid to the colleges and universities attended by recipient students, as the Dunn court concluded, either the absence of a secular-use restriction in the stat$u^{70}$ or the evidence that "pervasively sectarian" colleges were aid$\mathrm{ed}^{77}$ would be sufficient to justify the court's decision. The Tennessee tuition grants, however, were arguably not aid to institutions but rather aid to students-in the Everson pattern-and it can therefore be argued that the standards of Hunt and Tilton should not apply. ${ }^{78}$ The Tennessee tuition grant program provided aid to all eligible students in public as well as private colleges and umiversities. ${ }^{79}$ This type of aid progranı has never been tested in the Supreme Court, as Nyquist specifically reserved ruling on the constitutionality of such a scheme:

Because of the manner in which we have resolved the tuition grant issue, we need not decide whether the significantly religious character of the statute's beneficiaries miglit differentiate the present cases from a case involving some form of public assistance (e.g., scholarships) made available generally without regard to the sectarian-nonsectarian, or public-nonpublic nature of the institutions benefitted. ${ }^{80}$

Therefore, the court's conclusion that secular-use restrictions on general aid programs similar to Everson are constitutionally required may be seen as an overly broad reading of Everson and subsequent Suprente Court decisions. ${ }^{81}$ In fact, if individuals receive scholarships as part of a general state program of financial assistance to students, re-

75. Id.

76. Id. Although the court referred only to "restrictions," without expressly indicating that "secular use restrictions" were contemplated, it is clear that secular use restrictions were intended.

77. Id. If the aid were in the form of general aid to students, as opposed to direct aid to the colleges, there would be no need to determine if the schools were "pervasively sectarian." There would also be minimal contacts between the state and the sectarian colleges, and the entanglement branch of the three-part test would not become a factor.

78. See notes 39-54 supra and accompanying text.

79. Id. at 717 .

80. Committee for Pub. Educ. \& Religious Liberty v. Nyquist, 413 U.S. 756, 78283 n.38 (1973).

81. The court also cited Nyquist and Sloan as authority for the proposition that aid programs similar to that in Everson must be used solely for secular purposes. $384 \mathrm{~F}$. Supp. at 720 . 
gardless of whether they attend a public or private college, it might be a violation of the students' free exercise rights to discourage them from attending church-related colleges by refusing to pay scholarship money to such schools, or to force the student to insist that his tution not be spent on rehigious activities. ${ }^{82}$ Everson and Board of Education v. Allen, ${ }^{83}$ where the Supreme Court approved state loans of secular textbooks to parochial school students, imdicate that a state may not provide inherently sectarian aid, such as rehgious textbooks, to any group, but that it may give religiously neutral aid to a broad class of beneficiaries notwithstanding the fact that, in so doing, the state indirectly assists sectarian education. In both Everson and Allen the Court acknowledged that some students might not have been able to attend sectarian schools in the absence of aid, but maintained that so long as the aid was distributed among a broad class of beneficiaries and was religiously neutral, there would be no constitutional violation. ${ }^{84}$ Of course, the aid in Dunn would have appeared more like the Everson model had the state sent the money directly to the students. But there should be no practical difference between having students pay the school and having the state pay the scliool for the students. To hold otherwise is a clear elevation of form over substance. ${ }^{85}$

Furthermore, the plan in Dunn is distinguishable from the more limited program struck down in Nyquist in two important respects. First, a large percentage of the aid in Nyquist went to parents of children in Roman Catholic schools, ${ }^{86}$ which were found to be "pervasively sectarian"; in Dunn, however, sixty-three percent of all funds

82. See Areen, Education Vouchers, 6 HaRv. Crv. RIGHTS-CIV. LIB. L. REv. 466, 492 (1971); Note, supra note 6, at 909-15; Note, Education Vouchers: The Fruit of the Lemon Tree, 24 STAN. L. REv. 687, 689-90 (1972); cf. Luetkemeyer v. Kaufmann, 95 S. Ct. 167, 167-68 (1974) (White, J., dissenting). But see Committee for Pub. Educ. \& Religious Liberty v. Nyquist, 413 U.S. 756, 788-89 (1973).

83. 392 U.S. 236 (1968).

84. Board of Educ. v. Allen, 392 U.S. 236, 243-44 (1968); Everson v. Board of Educ., 330 U.S. 1, 17-18 (1947). Chief Justice Burger, concurring in part and dissenting in part in Nyquist, stated:

There are at present many forms of government assistance to individuals that can be used to serve religious euds, such as social security benefits or "G.I. Bill" payments, which are not subject to nonreligious-use restrictions. Yet, I certainly doubt that today's majority would hold those statutes unconstitutional under the Establishment Clause. 413 U.S. at 804.

See also Bertch v. Social Welfare Dep't, 45 Cal. 2d 524, 533-34, 289 P.2d 485, 491 (1955); Freund, supra note 28, at 1691.

85. These payments, in effect, become the student's money to spend on a college education. The facts in Dunn, therefore, are quite similar to those in Quick Bear v. Leupp, 210 U.S. 50, 80-82 (1908), where the Court held it was the Sioux, not the Government, who was purchasing a sectarian education. See note 12 supra.

86. 413 U.S. at 768. 
distributed during the 1973-74 school year went to students at church-related schools associated with diverse rehgious denominations, ${ }^{87}$ with none of the institutions serving as a vehicle for religious indoctrination..$^{88}$ Second, the tuition grants in Dunn were available to students at both public and private colleges, ${ }^{89}$ unlike the aid in Nyquist which was given only to parents whose children attended private elementary and secondary schools. ${ }^{20}$

Thus, Dunn squarely presented the issue left open by Nyquist: whether the general availability of aid, standing alone, is sufficient to render a fimancial assistance program constitutional. It is true that the plan at issue in Dunn was somewliat analogous to a general welfare program, a factor whose absence was stressed in Nyquist. ${ }^{91}$ It is also true, however, that the assistance plans approved in Everson and $\mathrm{Al}$ len contained inherent use restrictions; bus rides and secular texts are neutral forms of aid which cannot provide the direct advanceinent of religion which is repugnant to the establishment clause. ${ }^{92} \mathrm{~A}$ money grant is subject to no such inherent restriction. Thus, neither Everson nor Allen would appear to mandate a result contrary to that adopted by the Dunn court. Indeed, in the absence of some use restriction, either inherent in the aid itself or explicit on the face of the statute, it seems that a state aid-to-higher-education program would be unconstitutional. ${ }^{93}$

A very different view on the necessity of statutory use restrictions was the determining factor in Americans United for Separation of Church \& State v. Bubb, ${ }^{94}$ where a Kansas statute providing tuition grants to eligible college students at private accredited institutions within the state was lield constitutional. The court acknowledged that the aid flowed at least partially to the institutions, ${ }^{95}$ yet

87. 384 F. Supp. at 717.

88. Id. at 721 n.8.

89. Id. at 717 .

90. See 413 U.S. 756, 764-67 (1973).

91. 413 U.S. at 782-83 n.38; accord Sloan v. Lemon, 413 U.S. 825,832 (1973).

92. Board of Educ. v. Allen, 392 U.S. 236, 243-45 (1968); Everson v. Board of Educ., 330 U.S. 1, 17-18 (1947).

93. Cf. Meek v. Pittenger, 374 F. Supp. 639 (E.D. Pa. 1974), prob. juris. noted, 43 U.S.L.W. 3207 (Oct. 15, 1974). In Meek the district court concluded that state expenditures for non-public secondary and elementary schools would violate the primary effect brancil of the tripartite test if

the payment is made directly to parents as a reimbursement for expenses incurred in sending children to a sectarian school and the payment is not effectively restricted to reimbursement for expenses for identifiable secular nonsectarian pupil activities or needs. $374 \mathrm{~F}$. Supp. at 649.

94. 379 F. Supp. 872 (D. Kan. 1974).

95. Id. at 888. Because the aid could only go to students at private colleges, id. 
applied the Supreme Court's three-part test to upliold the statute, ${ }^{98}$ even though all of the colleges receiving aid were cluurcli-affiliated ${ }^{97}$ and the statute contained no secular use restriction. ${ }^{88}$ The court easily found that the secular purpose element of the three-part test was satisfied. ${ }^{99}$ In examining the "effect" of the aid, it noted that fourteen of the nineteen sclools receiving aid did not serve a "primarily sectarian mission." ${ }^{100}$ In spite of the fact that even these schoois sponsored some religious activities, the court did not deem the absence of a secular use restriction fatal since participation in the sponsored activities was voluntary. ${ }^{101}$

Finally, the court determined that the statute withstood entanglement scrutiny as to the fourteen primarily secular colleges due to the fact that the aid prograin was structured to avoid administrative entanglements between the state and the colleges, ${ }^{102}$ and to the minute potential for political divisiveness as a result of the granting of aid. ${ }^{103}$

at 876, and since all nineteen eligible institutions were church-related, id. at 878 , the tuition grant program was quite similar to that struck down in Nyquist. See Committee for Pub. Educ. \& Rehgious Liberty v. Nyquist, 413 U.S. 756, 780-83 (1973). The Tennessee tuition grants examined in Dunn, however, would not appear to fall within the Court's decision in Nyquist. See text accompanying notes 86-90 supra.

96. 379 F. Supp. at 887-88, 894-95.

97. Id. at 878 .

98. Id. at 876 .

99. Id, at 888 . The court said:

The reason for enacting the Statute is simple economics. . . The legislature is attempting to utilize all existing institutions to their optimum point and thereby reduce the state's financial responsibility for higher education. Id.

The court found that the state paid $\$ 1,150$ annually for each student in a tax-supported institution. By way of contrast, only one half of the students who attended private colleges were ehgible for aid, and the average grant was only $\$ 800$. Hence, the cost to the state was found to be at least $\$ 1,250,000$ a year less than if those students attended tax-supported institutions. Id. at 877 .

The court added that a second reason for the program was to enable needy students to attend the college of their choice. Id. at 888 .

100. Id. at 893 .

101. Id. at 893-94. The court appeared to be applying some form of the "no imposition" interpretation of the establishment clause. See Schwarz, supra note 6, at 692.

102. The State Education Commission had no authority to interfere with the operation of the colleges. 379 F. Supp. at 895.

103. The court noted:

At the college level, however, the potential for political fragmentation is unlikely. In Kansas there are nineteen eligible church colleges operating in sixteen local commumities. As noted earlier these colleges serve a primarily secular educational purpose and attract students of all faiths throughout the world. Because of the diversity of students and faiths represented on all the campuses, political involvement is less likely to be split along religious lines. Id.

The court also found that the five remaining institutions served a "substantially sectarian mission," id. at 893, and enjoined the State Education Commission from providing grants to students at those institutions, id. at 896. 
A much clearer case of aid to institutions as opposed to aid to students was presented in Roemer v. Board of Public Works, ${ }^{104}$ in which a Maryland statute providing grants to private colleges (some of which were church-affiliated), but containing a secular use restriction, ${ }^{105}$ was declared constitutional. As in $B u b b$, the court made a pro forma determination that the statute had a secular purpose. ${ }^{106}$ It then found that the aid would not have the "primary effect" of advancing religion because the church-related colleges were not "pervasively sectarian" and the funds could not be used for "specifically religious activity." 107 The court next considered the administrative and political entanglements generated by the legislation and concluded that the statute satisfied the third element of the three-part test. ${ }^{108}$ This conclusion was based on the absence of religious permeation at the church-related colleges, the "ideological neutrality" of the program, ${ }^{109}$ the relative lack of: control by the state over the school's internal affairs, ${ }^{110}$ and the small chance of pohitical divisiveness on rehgious grounds. ${ }^{111}$

104. 387 F. Supp. 1282 (D. Md. 1974), prob. juris. noted, 43 U.S.L.W. 3515 (Mar. $25,1975)$.

105. 387 F. Supp. at 1285.

106. Id. at 1286 .

107. Id. at 1287. Prior to 1972 , the grants could be used for any purpose by the recipient institutions. Following the Supreme Court's decision in Lemon and Tilton, the Maryland legislature added section 68 which reads: "None of the inoneys payable under this subtitle shall be utilized by the institution for sectarian purposes." MD. ANN. CODE art. $77 \mathrm{~A}, \S 68 \mathrm{~A}(1972)$.

Apparently the court ignored tlie "direct and immediate" language of Nyquist. Perhaps it believed, as Justice Powell indicated, that the apparent reformulation of the effect test did not signal a substantive cliange in the existing law. See Smith v. Smith, 43 U.S.L.W. 2393 (W.D. Va., Mar. 14, 1975) (post-Nyquist decision still using "primary effect" language).

108. 387 F. Supp. at 1288-91.

109. This factor might have been added to make the case appear more akin to the fact situations in Hunt and Tilton. The court said:

[T] he nentrality of the aid is dependent upon the essential character of the school. Where the secular aspects of a school may be separated from the sectarian, as in the case of these defendants, aid to the sectarian aspect, regardless of the form of the aid, will necessarily be religiously neutral. The aid in this prograin is restricted to the secular aspects of the institutions. Id. at 1290.

Cf. Note, supra note 6, at 904-05.

110. The court noted that the South Carolina statute examined im Hunt was far more entangling than the one before it:

In the South Carolina scheme, the state administrative agency acted as the recipient institution's landlord and acquired substantial control over the school's ability to set its own fees and charges. The Supreme Court found the South Carolina statute to be constitutional even though it established a schoolgovernmental relatiouship which was far more intimate and pervasive than any relationship likely to result from the statute now under consideration. Id. at 1290.

See Kauper, supra note 36, at 119.

111. The court quoted a statement from Tilton indicatimg that the prospects of politi- 
Assuming that the $B u b b$ court was correct in its conclusion that the Kansas program involved aid to institutions, Roemer and $B u b b$ should have applied the same standards in assessing the validity of the legislation before then. The Hunt and Tilton decisions require that state aid neither be given to pervasively sectarian institutions nor be used to carry out religious activity where the college is not pervasively sectarian. ${ }^{112}$ Accordingly, the $B u b b$ court decided that all colleges which had inore than formalistic relations with religious groups were ineligible for aid. ${ }^{113} \mathrm{But}$, in contrast to the Maryland statute at issue in Roemer providing that none of the state aid could be spent on sectarian activities, ${ }^{114}$ the $B u b b$ court admitted that a portion of the money granted by the state could be used to fund rehigious activity. In the court's view, this fact did not compel a constitutional violation so long as participation in the activities was voluntary: ${ }^{115}$

There is no way we can be sure the students will not take part in religious activities. We do not believe, lrowever, that the tuition grant program is unconstitutional because soine recipients become involved in religious activities. The church colleges . . . do not force religion on any students. The opportunity is there for religious participation but the degree of involvement depends totally upon the student. Religious participation is voluntary and is thus distinct from the education received at these cluurch colleges. ${ }^{116}$

The $B u b b$ emphasis on voluntariness seems to be misplaced. Voluntariness of student participation in rehgious activities supported by state funding should not be a determining factor in assessing the constitutionality of the legislation. Certainly church attendance itself is voluntary, but it is inanifest that the establishment clause bars a state froin building and maintaining a churcli. Moreover, the Supreme Court has indicated that "[ $[$ ] he absence of any eleinent of coercion ... is irrelevant to questions arising under the Establish-

cal divisiveness are less where aid is given to colleges and universities, than where it is given to elementary and secondary schools. It also pointed to the fact that most of the schools benefited under the program were church-affiliated, similar to the situation in Nyquist where eighty-five percent of the students benefited were Roman Catholic. Id. at 1291.

112. Hunt v. McNair, 413 U.S. 734, 743-45 (1973); Tilton v. Richardson, 403 U.S. 672, 679-82 (1971).

113. 379 F. Supp. at 893 . The findings of fact in Roemer indicated that the five eligible Maryland schools conformed closely to the colleges involved in Tilton and were less sectarian than the school in Hunt. 387 F. Supp. at 1294.

114. 387 F. Supp. at 1285 .

115. 379 F. Supp. at 892 .

116. $I d$. at 894 . 
ment Clause," ${ }^{\prime 117}$ at least in the context of tax reimbursement to parents of children in parochial schools, ${ }^{118}$ and prayer in public schools. ${ }^{110}$ Thus, the voluntary nature of sectarian activities, standing alone, should not guarantee the validity of a state aid provision.

The $B u b b$ court's reliance on volition, though, can be viewed from another perspective. The problem facing the court was the absence of an express restriction on the use of state funds for nonsectarian purposes. No argument could be made, as in Dunn, ${ }^{120}$ that the aid program might pass muster as a general "welfare" program for the benefit of students, in the Everson pattern, since the Kansas statute was limited to students at private colleges, ${ }^{121}$ all of which were related in some way to churches. ${ }^{122}$ Where then could the court fimd an assurance that the state funding would not be used to "establish" religion? The answer for the $B u b b$ court lay in the nature of the institutions benefiting from the aid.

As the court saw it, "the primary problem . . . is not whether a state may provide financial aid to schools with a sectarian mission but whether these colleges eligible for state aid . . . do indeed serve a sectarian mission." ${ }^{123}$ The $B u b b$ court thus dismissed the requirement of a restriction on the use of the aid as a matter of form over substance. So long as the college receiving aid does not "serve a sectarian mission" the court felt it could rely on the "emphasis on academic freedom"124 to provide an adequate safeguard against use of the state funds to promote a sectarian policy.

The step taken by the $B u b b$ court is a large one because it entails acceptance of a position which the Supreine Court has yet to embrace. The Kansas statute concededly has no provision which would prevent a clurch-related college from using state funds to pay salaries of religion instructors or to construct a new chapel. ${ }^{125}$ Yet this absence is not seen as fatal so long as the mam emphasis at the institution is on academics instead of rehigion. The strength of traditions of academic freedom, the greater independence of college students as compared to

117. Committee for Pub. Educ. \& Religious Liberty v. Nyquist, 413 U.S. 756, 786 (1973).

118. Id.

119. School Dist. v. Schempp, 374 U.S. 203, 222-23 (1963).

120. See notes $78-93$ supra and accompanying text.

121. 379 F. Supp. at 875 .

122. Id. at 878 .

123. Id. at 889 .

124. Id. at 891. "[A]t the college level the emphasis on academic freedom and the quest for truth necessitates absence of sectarian influence." Id.

125. Id. at 893-94. See KAN. Stat. ANN. §§ 72-6107 et seq. (1972). 
younger students, and the voluntary nature of the religious efforts are seen as adequate safeguards to assure that state funding will not support religious purposes. Thus, the need for an express statutory restriction is obviated.

The $B u b b$ approach has considerable appeal, primarily because it involves an examination of the substance of the aid programs, rather than a inere recitation of allegiance to the form of the transaction. ${ }^{126}$ The court, in effect, is reversing "the recurrent argument that all aid is forbidden because aid to one aspect of an institution frees it to spend its other resources on religious ends,"127 and using that argument to uphold state aid. While this notion is not expressed in $B u b b$, it is implicit in its reasoning. Requiring the states to restrict aid to secular uses accomplishes nothing of substance in the court's view, since the funds freed by the receipt of aid have no strings attached. The Supreme Court has not permitted this "freed funds" argument to prevent aid to churcli-related schools in situations where the school is not so "pervasively sectarian" that its sectarian and secular activities become inseparable. ${ }^{128}$ The $B u b b$ court would go further, lowever, adopting the position that the state funds do make possible the expenditure of money for sectarian purposes, while using that fact to sanction unrestricted aid. As long as restricted state funds free a like amount for unrestricted use, it is a meaningless formality to attach restrictions on the use of the inoney.

Viewed solely as a matter of logic, this argument is difficult to refute. What it fails to consider, however, is the original reason for establishing the formal requirements of statutory restrictions on use. The establishment clause is framed in absolute terms. To argue that the unrestricted provision of funds which inay be used for purely sectarian purposes is acceptable so long as the safeguards of academic environment provide assurances that a sectarian influence will not be exerted on students ignores the plain fact that state money is used directly to support a religious activity. Tliough the Suprene Court has labored to sanction limited and restricted funding by rejecting the "freed funds" argument, it is not likely the Court would entirely abandon the absolute prohibition of the first amendment, even in the face of the logical argument that restricted funding accoinplishes exactly the same purpose.

126. See 379 F. Supp. at 889, citing Lemon v. Kurtzman, 403 U.S. 602, 614 (1970).

127. Hunt v. McNair, 413 U.S. 734, 743 (1973).

128. See id.; Tilton v. Richardson, 403 U.S. 672, 679 (1971); Bradfield v. Roberts, 175 U.S. 291 (1899); cf. Walz v. Tax Comm'n, 397 U.S. 672, 674-75 (1970). 
In contrast to the Kansas statute, the Maryland legislation examined in Roemer did include an express restriction on the use of funds. ${ }^{129}$ To give legitimacy to this formal requirement, however, the state must oversee the use of its funds in order to guarantee that none can be traced directly to a purely religious activity. This element-the need for a government check on the use of restricted funding-leads to a serious problem with the third stage of the three-part establishment clause test, namely the danger of excessive entanglement. Arguably, the noncategorical grants involved in Roemer would necessitate greater government supervision than the one-time construction grants upheld in Hunt and Tilton; ${ }^{130}$ funds which may be used to pay salaries or to purchase texts might not be as "ideologically neutral" as funds earmarked for a building to be used for a secular purpose. Likewise, there is nothing about a noncategorical grant which would place an inherent restriction on its use and bring it into the same category with bus fares or the loan of secular texts. ${ }^{131}$ It may thus be argued that the state involvement necessary to guarantee adherence to the statutory restriction is very large where money grants are inade subject only to negative limitations, and indeed may impermissibly "entangle" the state in the operation of the school.

To assess the validity of this argument, it is important to recall that the "entanglement" element of the three-part test focuses on the nature and extent of surveillance and administrative control by the state. ${ }^{132}$ While buildings are indeed "non-ideological," the secular-use restrictions in both Hunt and Tilton necessarily apply to the use of the buildings. Hence, in Hunt and Tilton, as well as in Roemer, it is the nature of the instruction taking place in the colleges which must be examined in order to determine the presence or absence of sectarian use of state aid. ${ }^{133}$ The factual situation in Roemer, then, is not so dissimilar from those in Hunt and Tilton as to force a court to find an entanglement violation. As the Roemer court pointed out:

129. MD. ANN. CODE $\$ 68$ A (Supp. 1974); see Roemer v. Board of Pub. Works, 387 F. Supp. 1282,1285 (D. Md. 1974).

130. Hunt v. McNair, 413 U.S. 734 (1973); Tilton v. Richardson, 403 U.S. 672 (1971). See text accompanying noles 39-54 supra.

131. See notes 83-84 supra and accompanying text.

132. See Lemon v. Kurtzman, 403 U.S. 602, 619-21 (1971); Walz v. Tax Comm'n, 397 U.S. 664, 675 (1970).

133. Justice Brennan, in vigorous dissents in both Hunt and Lemon, argued that there was excessive entanglement because of the surveillance required over the content of teaching in the buildings constructed with government funds. 413 U.S. at 749; 403 U.S. at 642. If the Court did not find the administrative involvement excessive in these two cases, arguably the Roemer court was correct in finding no excessive entanglement in 
The classroom buildings provided in Tilton and Hunt are no more neutral in the abstract than the classrooin buildings which were maintained with public funds in Nyquist. The classes taught in the Tilton and Hunt classrooms are no inore neutral than the classes taught by publicly subsidized teachers in Lemon, all other things being equal. ${ }^{134}$

Armed with this reasoning, the Roemer court looked to academic freedom-the same element relied on in $B u b b$ - to support its holding that the state would not necessarily be involved in the day-today operations of the aided schools. At the secondary school level, where the relatively weaker academic tradition and the less independent attitude of the students provide no real check, the government would have to monitor the content of teaching to assure compliance with its restrictions. "Yet the Court could conclude that sucli monitoring would not be necessary at a college whicli maintained its academic freedom and integrity."135

The presence of the express restriction in the Maryland statute thus enabled the Roemer court to make use of the same built-in safeguards viewed as dispositive in $B u b b$ to prevent an entanglement problem. And, while the $B u b b$ court arguably was correct in its view that the use restriction is merely a formality, the presence of the limitation permitted the Roemer court to avoid, with the sanction of the Supreme Court, the absolute prohibition of the first amendnient.

\section{CONCLUSION}

These three federal district court decisions highlight the extreme difficulty of the issues surrounding a state's attempt to provide financial aid to private, church-affiliated institutions of higher learning either througli tuition payments or noncategorical grants. The Supreme Court treatment of the perplexing establishment clause questions guarantees the validity of a state aid program only if funds do not go to "pervasively sectarian" institutions, the statute expressly restricts use of funds to secular activities, and the government is not "excessively entangled" with the college in its efforts to police the use restrictions. The concepts of "pervasive sectariamism" and "excessive entanglement" are so elusive, however, that it is extremely difficult to predict with any confidence how the courts will view a specific aid program.

its situation. See also Kauper, Public Aid for Parochial Schools and Church Colleges; The Lemon, Dicenso, and Tilton Cases, 13 ARE. L. REv. 567, 586-87 (1971). 134. 387 F. Supp. at 1288-89.

135. Id. at 1289 . 
A state might, as Tennessee did, attempt to avoid these difficulties by channelling its funds through the students, thereby arguably effecting a general program of state assistance to students at both public and private institutions which would pass muster under the Supreme Court's holding in Everson. The approach does not, however, withstand close analysis, and it is likely that the Dunn court was correct in its demand that state aid to students be subject to "appropriate restrictions" in order that the express language of the establishment clause is not ignored.

The attempt made in $B u b b$ to avoid the necessity for an express use restriction likewise does not survive careful analysis, leading to the conclusion that state aid must be limited to use in purely secular programs if the aid is in the form of money. The Roemer analysis suggests that adequate safeguards do not automatically precipitate impermissible administrative entanglements, and shows the most promise as a constitutionally acceptable means of providing state aid to churchaffiliated colleges.

Regardless of the type of program adopted, the legislatures and the courts inust be prepared to deal with the perplexing constitutional questions as economic conditions place ever-increasing pressure on states to find a way to provide financial support for private higher education. At this point, all that can be said with certainty in the realm of direct money grants is that the "wall of separation" erected by the establishment clause has become a "blurred, indistinct, and variable barrier"130 which likely will not prove insurmountable.

136. Americans United for the Separation of Church \& State v. Dunn, 384 F. Supp. 714, 718 (M.D. Tenn. 1974), quoting Lemon v. Kurtzman, 403 U.S. 602, 614 (1971). 